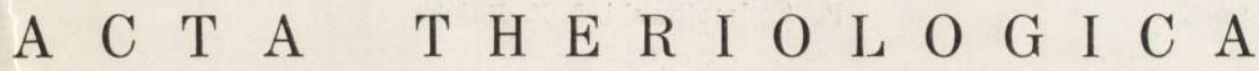

\author{
VOL. XVII, 4: $41-56$.
}

BIAEOWIEŻA

May, 1972

\author{
Roman AN DRZEJEWSKI \& Ewa RAJSKA
}

\section{Trappability of Bank Vole in Pitfalls and Live Traps}

[With 3 Tables \& 5 Figs.]

Studies were made in an isolated natural population of Clethrionomys glareolus of the trappability of different age groups of individuals, using either live traps or pitfalls, or both kinds of traps simultaneously. Trappability of bank voles in pitfalls is lower than in live traps. The older the group, the higher the trappability of different groups of individuals in live traps, whereas trappability in pitfalls does not exhibit such differentiation. When live traps and pitfalls are used together differentiation of trappability in live traps is the same as when these traps are used on their own. Trappability in live traps increases with the age of individuals, while that in pitfalls decreases. Individuals introduced into the population are characterized, regardless of their age, by trappability similar to that of the group of youngest individuals in the population. As the age group grows older differences in trappability increase among its members. It was found that an individual's weight does not determine its trappability. The results obtained are in agreement with G liwicz's hypothesis (1970) suggesting that the trappability of different age groups is due to the social organization of the population.

\section{INTRODUCTION}

The term "trappability " defines the ratio of number of captures of an individual or group of individuals to the number of captures capable of taking place in relation to these individuals within a defined period ( $\mathrm{Pe}$ trusewicz \& Andrzejewski, 1962; Andrzejewski, 1963).

Differences in the trappability of rodents when using different kind of traps, although the cause of such differences is rarely given, are widely known (Buchalczyk \& Pucek, 1968; Grodziński, Pucek \& Ryszkowski, 1966; Pucek, Ryszkowski \& Zej$\mathrm{d} a, 1969)$.

Andrzejewski \& Wroclawek (1963) described methods of trapping small rodents in baited pitfalls. These authors, and also $\mathrm{Ch}$ e 1 k ow ska (1967), found that trappability of bank voles is greater in 
a grid of such pitfalls than in an analogical grid of live traps. In G 1 iw i c z's (1970) opinion, however, the trappability of Clethrionomys glareolus ( $\mathrm{Schreber}, 1780$ ) depends on the age of individuals and on the age structure of the population at the time. Hence this author suggests that one of the causes of different trappability may be the place of each age group in the social organization of a population. Younger individuals occupying a lower position in the social organization are caught relatively less often, as the result of the influence of individuals occupying higher positions in this organization (G liw ic z, 1970).

The purpose of the present study was to ascertain whether differences revealed by the use of live traps in the trappability of different groups in a population are the same if pitfalls, or pitfall and live traps combined, are used.

The studies were made in a bank vole population (the same as that examined by G liw i c z, 1970) living on a 4-hectare island in a lake in north-east Poland (Mazurian lake district). The island was covered by a forest belonging to 4 phytocenological associations: Tilio-Carpinetum typicum, Tilio-Carpinetum stachyetosum silvaticae, Circeo-Alnetum and Salici-Franguletum ( $\mathrm{Traczyk}$, 1965). The distance of the island from the nearest shore of the lake ruled out any significant exchange of individuals between the island and shore and the island population can be considered as isolated (Andrzejewski, Petrusewicz \& Waszkiewicz-Gliwicz, 1967).

The whole island was covered by a grid of 150 trapping sites spaced at $15 \times 15 \mathrm{~m}$ intervals. In 1968 one pitfall of the type used by Andrzejewski \& Wrockawe k (1963) was placed on each trap site, and in 1969 and 1970 one pitfall $(80 \mathrm{~cm}$ deep) was placed on each site with 3 live traps in its immediate vicinity. Both pitfalls and live traps contained oats as bait. Five series of captures were carried out (lasting 14 days in 1968 and 10 days in 1969 and 1970) in the second half of April, first half of June, second half of July, first half of September and second half of October. Intervals between the consecutive series were 47 days and the start of the first series depended on when the ice melted in the lake, making it possible to reach the island.

During each series of catches the traps were kept continuously set and rodents released from live traps and pitfalls at 7 a.m. and 7 p.m. All rodents caught were individually marked by toe-clipping. The following information was recorded for the animals caught, number of individual, its body weight, sex, trap site number and type of trap.

G liwicz et al. (1968) found that two-weekly trappings of the C. glareolus population on this same island by the $C M R$ method, using live traps only, are fully sufficient to ensure that practically all individuals are caught at least once or more. The consecutive series of captures are carried out from spring to late autum, 
the first series taking place before the young individuals leave the nest, and final series after the end of reproduction period. In consequence it can be said that individuals caught in the trapping series for the first time must have reached trappable age between end of one series of catches and the end of the subsequent series. As the bank vole leaves the nest on the 21st day after birth (K ow a ls ki, 1964), the period in which the individuals caught in each trapping series were born can be calculated. As the result of this trapping system all the individuals living on the island can be divided into cohorts and their age defined with accuracy to \pm 3 weeks. It is thus possible to distinguish 4 cohorts on the island: the spring cohort, the individuals of which are caught for the first time in the June trapping series, the early summer cohort, the individuals of which are caught for the first time in the July trapping series, the late summer cohort, the individuals of which are caught for the first time in the September trapping series and the autumn cohort, the individuals of which are caught for the first time in the October trapping series.

Table 1

Number of captures in successive trapping series.

\begin{tabular}{|c|c|c|c|c|c|c|c|c|}
\hline & $\begin{array}{l}\text { Year, } \\
\text { month }\end{array}$ & $K_{0}$ & $K_{1}$ & $\begin{array}{l}\text { Cohort } \\
K_{2}\end{array}$ & $K_{3}$ & $K_{4}$ & $K_{i}$ & $\begin{array}{l}\text { All } \\
\text { popu- } \\
\text { lation }\end{array}$ \\
\hline 1968 & $\begin{array}{r}\text { IV } \\
\text { VI } \\
\text { VII } \\
\text { IX } \\
X\end{array}$ & $\begin{array}{r}324 \\
182 \\
69 \\
42 \\
11\end{array}$ & $\begin{array}{r}1916 \\
1716 \\
1538 \\
758\end{array}$ & $\begin{array}{l}728 \\
377 \\
377 \\
\end{array}$ & $\begin{array}{l}399 \\
129\end{array}$ & 19 & & $\begin{array}{r}324 \\
2098 \\
2513 \\
2356 \\
1254\end{array}$ \\
\hline 1969 & $\begin{array}{r}\text { IV } \\
\text { VI } \\
\text { VII } \\
\text { IX } \\
\mathrm{X}\end{array}$ & $\begin{array}{r}246 \\
214 \\
210 \\
135 \\
22\end{array}$ & $\begin{array}{r}299 \\
237 \\
164 \\
70\end{array}$ & $\begin{array}{l}603 \\
802 \\
362\end{array}$ & $\begin{array}{l}446 \\
255\end{array}$ & 324 & $\begin{array}{r}221 \\
118 \\
118 \\
50 \\
16\end{array}$ & $\begin{array}{r}467 \\
631 \\
1168 \\
1597 \\
1049\end{array}$ \\
\hline 1070 & $\begin{array}{c}\text { IV } \\
\text { VI } \\
\text { VII } \\
\text { IX } \\
\mathrm{X}\end{array}$ & $\begin{array}{r}142 \\
194 \\
165 \\
91 \\
10\end{array}$ & $\begin{array}{r}221 \\
330 \\
125 \\
76\end{array}$ & $\begin{array}{r}884 \\
1123 \\
883\end{array}$ & $\begin{array}{l}691 \\
520\end{array}$ & 61 & 571 & $\begin{array}{r}142 \\
415 \\
1379 \\
2030 \\
2121\end{array}$ \\
\hline
\end{tabular}

In addition individuals which had lived on the island in winter (old adults cohort, composed of individuals of different ages) (Gliwicz et al. 1968) occur in the population. These individuals reach the reproduction period simultaneously in spring, exhibit uniform mortality during the summer period, irrespective of their age, and are always the oldest in the population irrespective of their absolute age. They can therefore be treated as a homogeneous group in studies on behaviour and social organization of the population.

In view of the opinions held by many authors that individuals introduced into a population at first occupy the lowest positions in the social organization of that population (Andrzejewski, Petrusewicz \& Walkowa, 1959 groups of individuals of $C$. glareolus from alien populations were twice introduced into the island population, i.e. in the spring of 1969 and autumn of 1970. These groups had 
no identified age; they undoubtedly differed in age and represented the age structure of a bank vole population characteristic of the periods in which they were introduced. Trapping of individuals for introduction were made with live traps set at random in an area excluding the island. The rodents caught were kept in cages for $1-2$ weeks, then the individuals intended for introduction were marked with individual numbers, their sex determined, after which they were weighed and immediately released in the middle of the island study area. The time of relase of the introduced individuals took place one week before the April trapping series in 1969 and October series in 1970. In this way after introduction it was possible to distinguish in the populations, in addition to the cohorts of uniform age, also the group of introduced individuals of various ages and to compare its trappability with that of the other local individuals.

The material analysed in the present study consists of 15 trapping series carried out in 1968, 1969 and 1970. The numbers of the different cohorts and numbers of the whole population are given in figure 1, the number of captures of the cohorts and whole population during the course of the consecutive trapping series in table 1 . During the study period a total of 131500 trap were set and 19560 captures of 1430 individuals obtained.

\section{ANALYSIS OF MATERIAL}

\subsection{Dynamies of the Population and of the Different Cohorts}

The number of different individuals caught in a cohort during a trapping series is the number of animals in this cohort during the trapping time (of this series). The total number of different individuals caught during a trapping series represent population numbers during the period of this series (Gliwicz et al. 1968). Analysis was made in the same way as done by Gliwicz et al. (1968) of whether during trapping time, when pitfalls only are used, there are individuals caught in one trapping series, and not recorded in the consecutive series, but recorded in one of the later series. It was found that the percentage formed by such individuals when using this trapping method is from 5 to $10 \%$ in different trapping series, these individuals belonging to all age categories currently present on the island. This made it necessary to add these individuals to population numbers assessed during the period of the trapping series in which they failed to appear.

It may also be assumed that the number of individuals in a trapping series was even greater, by the number of those individuals which did not appear in the trapping series, and did not survive until the subsequent trapping series and thus never appeared again. Since there are no grounds for accepting the hypothesis that mortality of not-appearing individuals differs from that of individuals caught in the trapping series, the number of individuals which did not appear in the series and did not survive to the subsequent series was assessed by multiplying the number of individuals which disappeared from the population 
between two series by the percentage of individuals not appearing in the second of these series.

Thus the numbers of these animals in every trapping series in 1968 were composed by individuals caught in this series, plus the individuals which were not caught in the series but were caught in later series, plus the number of individuals estimated on the basis of mortality and index of failure to appear. This last number of individuals fluctuated within limits of 5 to $8.5^{0} \%$ of the individuals of a population.

An analogical analysis made for captures in pitfalls and live traps set simultaneously (for 1969 and 1970) did not reveal individuals which had not appeared in any series of trappings, which permitted of estimating population numbers after Gliwicz et al. (1968).

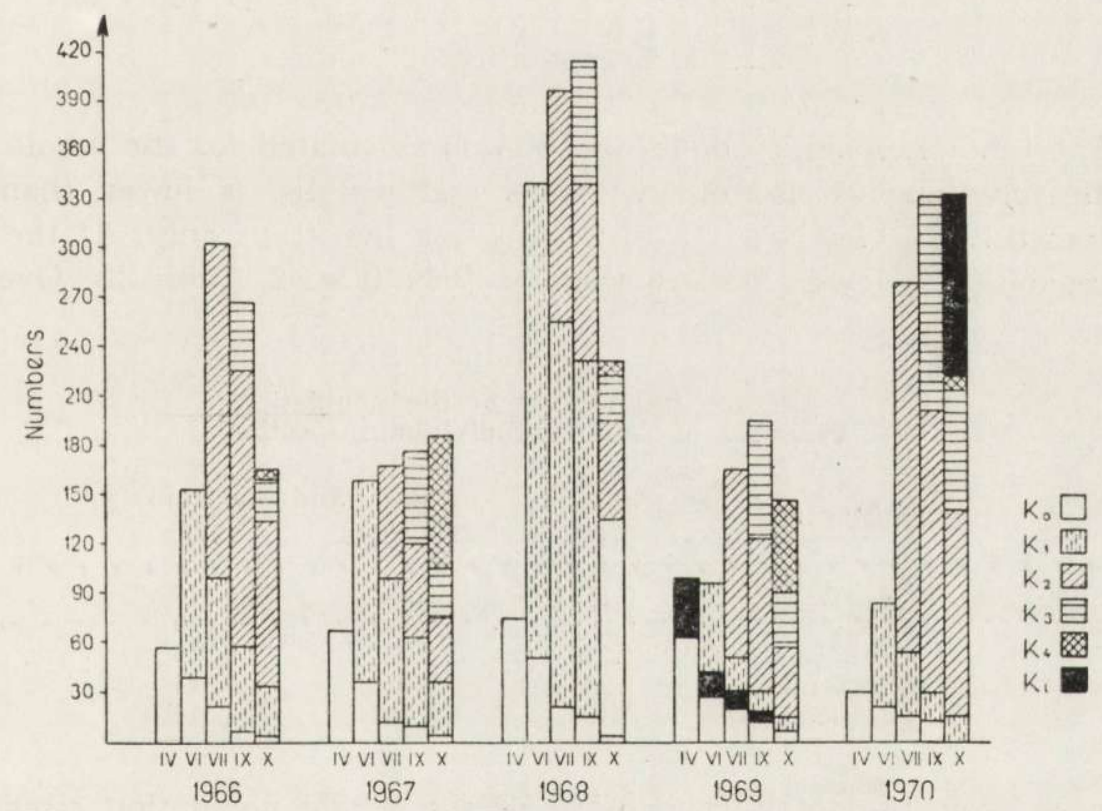

Fig. 1. Dynamics of numbers and age structure of a population of C. glareolus.

Starting with the above analysis, calculation was made of dynamics of numbers of the cohorts and the whole study population for 1966 in the study by Gliwicz et al. (1968), for 1967 in the study by Gliwicz (1970), 1968 in the study by Petrusewic z et al. (1971) and for 1969 an 1970 originally for this analysis. As these dates are used later to calculate the trappability of the different cohort and to compare this value using different methods, we have given here the whole dynamics of population numbers for bank voles on the island from 1966-1970 (Fig. 1). 


\subsection{Analysis of Trappability}

3.2.1. Trappability Using Pitfalls

The author's own data obtained from trapping rodents on the island in 159 pitfalls were compared with the trappability obtained by G liw i c z (1970) when trapping with live traps on the same 159 sites. Trappability of the different cohorts and the whole population in pitfalls is lower than in live traps (Fig. 2).

At the same time the trappability of different cohorts fails to exhibit differences in the consecutive trapping series (Fig. 2).

\subsubsection{Simultaneous Use of Live Traps and Pitfalls}

\subsubsection{Trappability of Cohorts}

The total trappability of the population calculated for the whole year, with simultaneous use of live traps and pitfalls, is lower than that obtained by Gliwicz (1970) when using live traps only. At the same trappability is lower in 1970 than in 1969 (Fig. 2, Table 2). Over the

\section{Table 2}

Average trappability of the population (Number of captures/individual/inspection).

\begin{tabular}{lccc}
\hline Month & Pitfalls & \multicolumn{2}{c}{ Pitfalls and life traps } \\
& 1969 & 1970 & 1971 \\
\hline April & 0.157 & 0.214 & 0.246 \\
June & 0.221 & 0.253 & 0.239 \\
July & 0.228 & 0.371 & 0.250 \\
September & 0.203 & 0.428 & 0.314 \\
October & 0.193 & 0.357 & 0.314 \\
\hline
\end{tabular}

annual cycle the total trappability of the whole population rises from April to September, to decrease in the October trapping series (Fig. 2).

Trappability obtained in live traps in both years so greatly exceeds that obtained in pitfalls that variations in trappability over the annual cycle are primarily determined by live trap captures. Trappability in pitfalls when live traps are present is lower than that obtained when pitfalls only were used.

Variations in trappability in live traps over the yearly cycle are similar to those obtained by Gliwicz (1970) using live traps only. Trappability increases from April to September, to decrease again in the October trapping series. Trappability in pitfalls is generally maintained on a similar level from April to September. The October trapping 


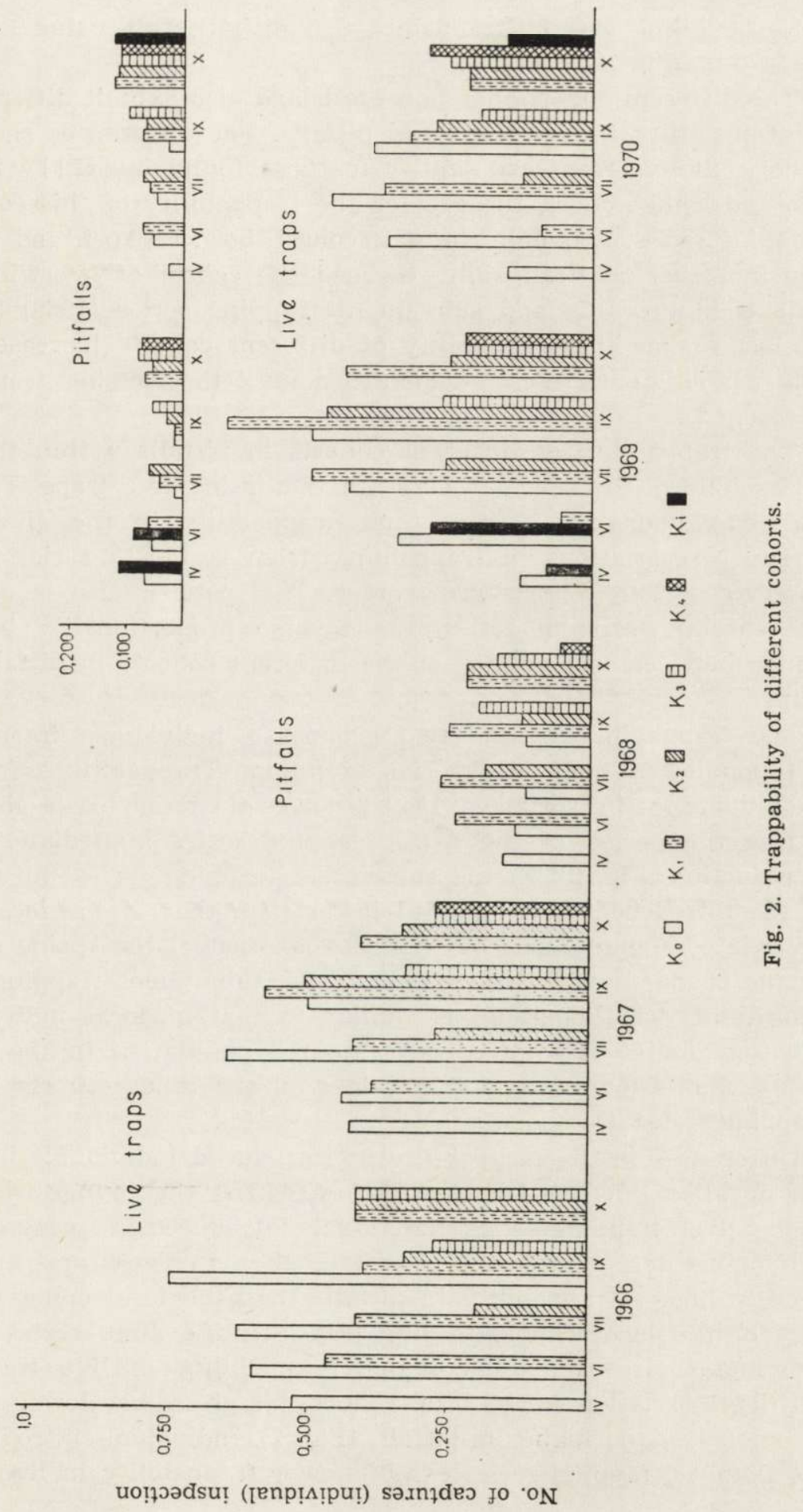


series exhibits greater trappability in pitfalls, this value being higher in 1970 than in 1969 (Fig. 2).

The different cohorts born on the island also exhibit different degrees of trappability in live traps and pitfalls. The differences shown by the cohorts in live traps are similar to those found by Gliwicz (1970). The older the cohort, the greater the trappability of this cohort in the trapping series. It is only the first cohort, born in April and May, which can in respect of trappability exceed the cohort of overwintered individuals in the July and subsequent trapping series (1969) (Fig. 2). At the some time the trappability of different cohorts increases with age (Fig. 2). This pattern is not disturbed until the October trapping series is reached.

The trappability of different cohorts in pitfalls within the trapping series follows the reverse course to that using live traps. The younger the individuals, the greater their trappability in the given trapping series. No variations in trappability from series to series is however observed as the cohorts grow older. This pattern also is disturiced in the autumn trapping series, the reverse proportionality being maintained between trappability of the different cohorts in pitfalls and live traps.

The trappability of the two groups of individuals introduced into the population deserves special attention. Trappability of introduced individuals in the spring of 1969 is lower than that of local individuals during the period of the April trapping series immediately following introduction (Fig. 2). In the subsequent trapping series the trappability of the introduced cohort is still lower than that of the local cohort of overwintered individuals but higher than that of the spring cohort born on the island. It would seem that in the subsequent trapping series the trappability of this group is similar to that of local individuals. The group of individuals introduced into the population in the autumn of 1970 exhibits lower trappability than all the other cohorts in the first trapping series (October).

Differences in the trappability of introduced individuals in live traps and pitfalls follow the same pattern as that for the youngest local cohorts in the given trapping series. Individuals introduced in spring (April 1969) exhibit greater trappability in pitfalls than in live traps, and simultaneously higher trappability in pitfalls than the local cohort, and lower that of the local cohort in live traps. In the June series introduced individuals already exhibit higher trappability in live traps than in pitfalls. In relation to the local cohort this group has lower trappability in live traps, and higher in pitfalls (Fig. 2). Individuals introduced before the October trapping series exhibit lower trappability in live traps than 
the local cohorts, and similar trappability in pitfalls to that of the other cohorts (Fig. 2).

The differences in trappability between live traps and pitfalls discussed above are clearly visible when live trap trappability is presented as the percentage of all captures found for the cohort in the trapping series (Fig. 3).

3.2.2.2. Trappability of Different Individuals in Live Traps and Pitfalls

Differences in trappability between individuals have been presented in the form of distributions of the number of individuals which reached

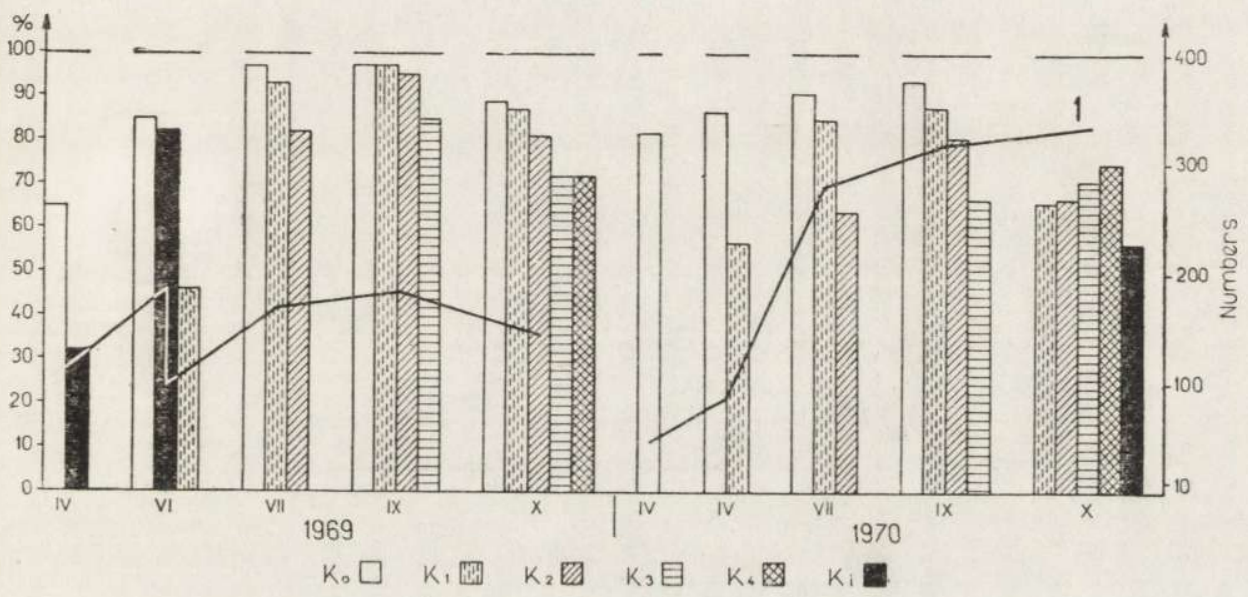

Fig. 3. Trappability (per cent of captures in live traps).

1 - numbers.

a defined number of captures in pitfalls or live traps in one trapping series (Fig. 4).

Bearing in mind the fact that the trappability of a cohort depends on its age, analysis was made jointly of individuals in all cohorts of uniform age, irrespective of the phenological time of entry of a cohort into the population (attainment of trappable age). For instance the individuals of cohort $K_{1}$ in the June trapping series $+K_{2}$ in the July series $+K_{3}$ in the September series $+K_{4}$ in the October series were added together, from both years jointly. Similarly cohort $K_{1}$ in July (that is, when it was 6 weeks older) was added to cohort $K_{2}$ in September etc.

Cohorts which have chances of being caught for the first time in the trapping series are characterized by distribution indicating numerous occurrence of individuals with a low number of captures and sporadic Acta theriol. 4 
occurrence of individuals with a large number of captures. In both distributions the maximum number of individuals have one capture each, but the distribution of captures in pitfalls is a random distribution, i.e. there is no differentiation here in the trappability of the different
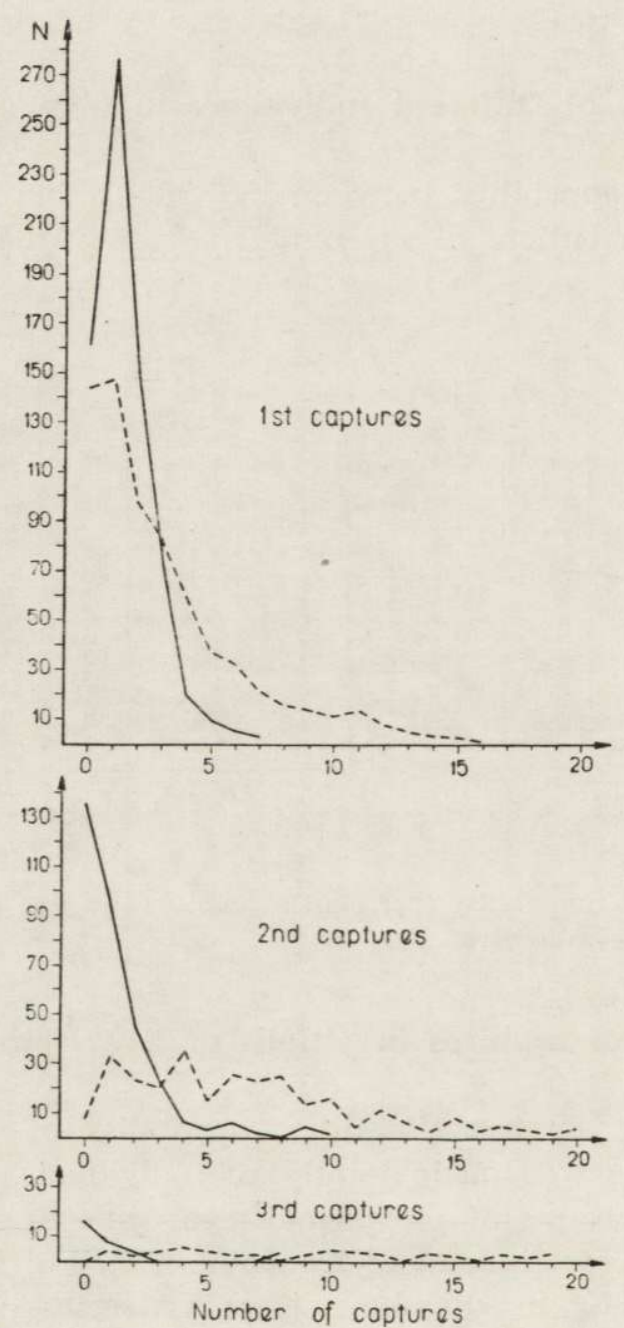

Fig. 4. Distribution of number of individuals caught $n$ times in pitfalls, and live traps.

individuals in a cohort. Individuals with one capture form $39 \%$ and the maximum number of captures attained by 1 individual is 7 . Individuals with one capture in live traps form only $21 \%$ and one individual reaches as much as 16 captures during one trapping series (out of twenty possible) 
(Fig. 4). This distribution is not a random distribution, this being checked by the chi-square method.

Among older individuals with one trapping series (that is, with 6 weeks) the process of differentiation of trappability intensifies. The number of captures attained by individuals in live traps varies from 0 to 20 , with very low obliqueness of distribution (modal average 4 captures and this number of captures is characteristic of $11.4 \%$ of the individuals) (Fig. 4).

The trappability of individuals which have already occurred in 3 trapping series (are about 20 weeks old) is very varied (Fig. 4). The distribution of captures in live traps is shown by a line almost parallel to the axis of ordinates in the range of 0 to 15 captures per individual (out of 20 possible). The distribution of captures in pitfalls has a range of $0-8$

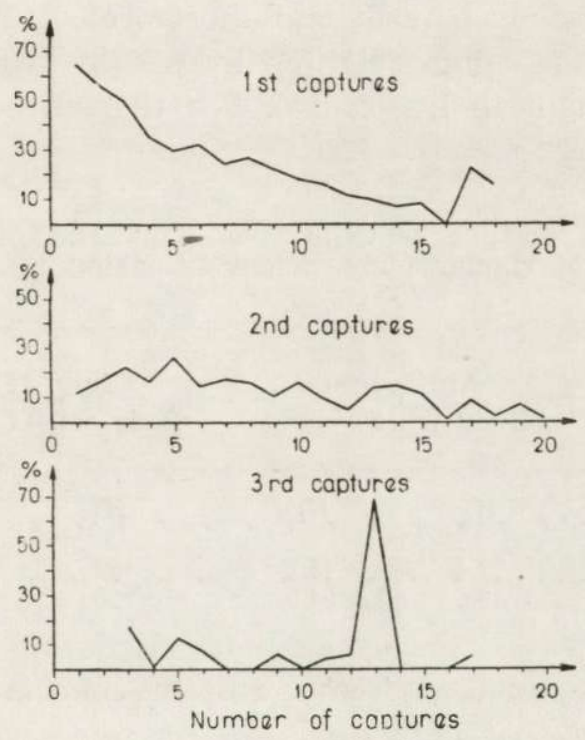

Fig. 5. Trappability and percentage of captures in pitfalls (data for 1969 and 1970 treated jointly).

captures per individual, characterizing $96.5 \%$ of the individuals having $0-3$ captures.

It was also ascertained whether there is a relation between the number of captures in live traps and in pitfalls for different individuals. For this purpose calculation was made of what percentage is formed by captures in pitfalls among all the captures of individuals which in the trapping series were caught once, twice, 3 times etc. The material was analysed in groups of individuals of uniform age, set out as above (Fig. 5). Among individuals of a cohort which is the youngest in a series 
the number of captures in pitfalls is greater, the smaller the number of captures of a the individual taking place during a trapping series (i.e. it has lower trappability). In the next trapping series this relation disappears and the percentage of captures in pitfalls is constant, irrespective of the trappability of an individual during the trapping series. In the third trapping series for the cohort almost all the individuals are caught in live traps only.

\subsection{Weight of Individuals Caught in Pitfalls and Live Traps}

As the mechanism closing the trap was set in motion by the pressure of the animal's legs on it, a check was made to see whether differences in trappability of different individuals are not caused by the force with which they press this mechanism and therefore simply by the weight of these individuals (a cohort lighter in weight would have smaller chances of being caught in live traps). For this purpose individuals of

Table 3

Trappability (in per cent) in live traps and pitfalls of individuals of similar body weight belonging to different cohorts.

\begin{tabular}{lcccc}
\hline & $\begin{array}{c}\text { April, 1969 } \\
\text { Body wt. 20-25 }\end{array}$ & $\begin{array}{c}\text { July, 1970 } \\
\text { Body wt. 17-20 g }\end{array}$ \\
\hline Cohorts & $K_{0}$ & $K_{i}$ & $K_{1}$ & $K_{2}$ \\
\hline Live traps & 73.4 & 45.1 & 82 & 61 \\
Pitfalls & 26.6 & 54.9 & 18 & 39 \\
\hline
\end{tabular}

uniform weight were selected from different cohorts in two series of catches. It was found that individuals of the same weight retain their different trappability according to their appurtenance to a cohort (Tab. 3).

\section{DISCUSSION}

Comparison of trappability in live traps and pitfalls in an isolated population of $C$. glareolus showed that trappability in pitfalls is lower than in live traps. This is a result at variance with data obtained by Andrzejewski \& Wrocławek (1963) and Chełkowska (1967).

The trappability of individuals of $C$. glareolus in live traps depends on the age of the individuals and the age structure of the population at the time (G liw ic z, 1970). When rodents were trapped in pitfalls differen- 
ces of this kind did not occur and all age groups in the population were caught with similar frequency. When rodents were trapped using both live traps and pitfalls the degree and differentiation of trappability in live traps is the same as when trapping in live traps only. Trappability in pitfalls in this case is even lower than when trapping with pitfalls only, a reverse tendency being observable in the trappability of different age groups: the younger the given cohort, the greater its trappability in pitfalls (Fig. 2).

The hypothesis might be reached that the reverse relation between trappability of the cohort in pitfalls and traps is the result of the different way in which capture takes place in these two kinds of traps, connected with the rodent's weight. Analysis of the trappability of individuals of the same weight belonging to different cohorts does not confirm this hypothesis (Tab. 3).

The fact of the low trappability of the groups of individuals introduced into the study population deserves special attention. The group of individuals introduced in spring, despite the fact that it consists of individuals similar in age to the local individuals, exhibits lower trappability in live traps and higher trappability in pitfalls than the local individuals. During the subsequent trapping series ( 6 weeks later) this group continues to exhibit slightly lower trappability than that of local old adults, but higher than that in the period immediately after introduction and higher than that of younger individuals - the first cohort born in the given year (Fig. 2).

The group of individuals introduced into the population in autumn, after reproduction ends, exhibits the lowest trappability in live traps in relation to the 4 cohorts born in the study population, despite the fact that the introduced group consists of individuals of the various age found in the whole population (Fig. 2).

Andrzejewski, Petrusewicz \& Walkowa (1959) and Calhoun (1959) found that individuals introduced into a population occupy the lowest position in its social organization. The low trappability exhibited by the group of introduced individuals, regardless of its current age structure, and therefore the similar behaviour of introduced individuals to that of the youngest cohort newly entering the population, is fully in agreement with one of the hypothesis put forward by G li wi c z (1970) as to the overruling importance of the social factor in defining the trappability of different age groups in the population.

As the cohort ages in the population, differences in trappability increase among its members, with lesser differences in trappability in pitfalls (Fig. 4). Reduction in the percentage of captures in pitfalls for individuals as their trappability (in live traps) increases thus affects not only 
different age groups but also different individuals within these groups (Fig. 5).

The question as to whether repeatedly caught individuals are not caught in pitfalls because they are caught in live traps soon after the latter are set, and consequently have no chance of being caught in pitfalls, while infrequently caught individuals approaching the traps later find that the live traps are occupied by frequently caught individuals, or that frequently caught individuals, by actively occupying live traps, oblige the infrequently caught individuals to make use of pitfalls, remains unsolved.

If trappability in different forms of traps depends on the social relation currently prevailing in a population between its individuals it is possible that the contradiction between the results obtained by A ndrzejewski \& Wrocławek (1963) and Chełkowska (1967), who obtained higher trappability in pitfalls than in live traps, and the opposite results presented in this study can be explained by the different social organization of the population depending on the ecological situation in which the population exists at the time of study.

\section{REFERENCES}

1. A ndrzejewski R., 1963: Processes of incoming, settlement and disappearance of individuals and variations in the numbers of small rodents. Acta theriol. 7: $169-213$.

2. Andrzejewski R. \& Wrocławek H., 1963: Metal cylinders as a livetrap with a bait. Acta theriol. 6: 297-300.

3. Andrzejewski R., Petrusewicz K. \& Walkowa W., 1959: Preliminary report on results obtained with a living traps in a confined population of mice. Bull. Acad. pol. Sci. Cl. II, 7: 367-370.

4. Andrzejewski R., Petrusewicz K. \& Waszkiewicz-Gliwicz J., 1967: The trappability of Clethrionomys glareolus (Schreber, 1780) and other ecological parameters obtained by the CMR capture method. Ekol. pol. A, 15: $710-725$.

5. Buchalczyk T. \& Pucek Z., 1968: Estimation of the numbers of Microtus oeconomus using the Standard Minimum method. Acta theriol. 13, 2: 461-482.

6. Chelkowska H., 1967: An attempt at comparing two methods of trapping small rodents (in pitfalls and live traps). Ekol. pol. A, 15: 779-785.

7. Gliwicz J., 1970: Relation between trappability and age of individuals in a population of the bank vole. Acta theriol., 15, 2: 15-23.

8. Gliwicz J., Andrzejewski R., Bujalska G. \& Petrusewicz K., 1968: Productivity investigation of an island population of Cletrionomys glareolus (S c hreber, 1780). I. Dynamics of cohorts. Acta theriol. 13: 401-413. 
9. Grodziński W., Pucek Z. \& Ryszkowski L., 1966: Estimation of rodent numbers by means of prebaiting and intensive removal. Acta theriol. 11, 10: $297-314$.

10. Kowalski K. (Ed.) 1964): Klucze do oznaczania kręgowców Polski. Część V. Ssaki-Mamalia. Państw. Wyd. Nauk., 1-280. Warszawa-Kraków.

11. Petrusewicz K. \& Andrzejewski R., 1962: Natural history of a freeliving population of house mouse (Mus musculus Linneaus) with particular reference to grouping within the population. Ekol. pol. A, 10: 85-122.

12. Petrusewicz K., Bujalska G., Andrzejewski R. \& Gliwicz J., 1971: Productivity processes in an island population of Clethrionomys glareolus. Ann. zool. Fennici 8: 127-132.

13. Pucek Z., Ryszkowski L. \& Zejda J., 1969: Estimation of average length of life in bank vole Cletrionomys glareolus ( $\mathrm{Schreber}, 1780$ ). [In "Energy flow through small mammal populations", Eds. Petrusewicz K. \& Ryszkowski L.], Państw. Wyd. Nauk.: 187-201, Warszawa.

14. Traczyk H., 1965: Roślinność Wyspy Dzikiej Jabłoni na Jeziorze Bełdańskim (The vegetation of the Wild Apple Tree Island on the Lake Beldańskie). Fragm. Flor. Geobot. 11: $541-545$.

Accepted, December 1, 1971.

Institute of Ecology,

Polish Academy of Sciences,

Dziekanów Leśny n/Warszawa, Poland.

\section{Roman ANDRZEJEWSKI i Ewa RAJSKA}

\section{ŁOWNOSC NORNICY W CYLINDRY I PUŁAPKI ŻYWOEOWNE}

\section{Streszczenie}

W izolowanej (zamieszkującej wyspę) naturalnej populacji Clethrionomys glareolus (S c hreber, 1780) badano łowność poszczególnych grup wiekowych oraz osobników introdukowanych używając pułapek żywołownych, cylindrów lub pułapek i cylindrów równocześnie.

Badania wykazały, że łowność w cylindry jest mniejsza niż w pułapki żywołowne (Ryc. 2, Tab. 2). Łowność nornic w pułapki jest uzależniona od wieku osobników i składu wiekowego populacji w danym czasie. Łowność poszczególnych grup osobników jest tym większa, im dana grupa jest starsza. W czasie połowów w cylindry zróżnicowanie takie nie wystąpiło i wszystkie grupy wiekowe w populacji łowiły się $\mathrm{z}$ podobną częstością. Przy połowach gryzoni równocześnie w cylindry i pułapki wysokość i zróżnicowanie łowności w pułapki jest takie same jak przy połowach tylko w pułapki. Łowność w cylindry jest w tym wypadku jeszcze niższa niż przy połowach tylko w cylindry, przy czym wydaje się zaobserwować odwrotna tendencja w łowności poszczególnych grup wiekowych: im dana kohorta jest młodsza tym łowność w cylindry ma większą (Ryc. 2 i 3 ). 
Osobniki introdukowane do populacji wiosną, o wieku podobnym do osobników miejscowych, wykazują łowność niższą w pułapki a wyższą w cylindry niż osobniki miejscowe. W miarę przebywania w populacji grupa ta uzyskuje łowność wyższą niż w okresie po introdukcji i wyższą niż u osobników młodych ale nieco niższą od przezimków miejscowych. Osobniki introdukowane jesienią po zakończeniu rozrodu wykazują najniższą łowność w pułapki w stosunku do grup wiekowych urodzonych $\mathrm{w}$ badanej populacji, mimo, że introdukowana grupa składa się z osobników o wieku zróżnicowanym podobnie do całej produkcji (Ryc. 2 i 3).

W miarę starzenia się danej grupy wiekowej wzrasta zróżnicowanie łowności jej osobników w pułapki przy mniejszym zróżnicowaniu łowności w cylindry (Ryc. 4 i 5).

Stwierdzono, że ciężar osobników nie decyduje o ich łowności (Tab. 3), a uzyskane wyniki są zgodne z hipotezą Gliwicz (1970) sugerującą, że łowność różnych grup wiekowych wynika $\mathrm{z}$ socjalnej organizacji populacji. 